\title{
ALTERNATIVE APPROACHES FOR LONG-TERM DEFENCE PLANNING
}

\author{
Teodora Petrova ${ }^{1}$ and Zhivo Petrov ${ }^{2}$ \\ ${ }^{1}$ Assist. Prof. Ph.D., Georgi Benkovski Air Force Academy, Dolna Mitropoliya, Bulgaria, \\ teodorapetrova33@abv.bg \\ ${ }^{2}$ Assist. Prof. Ph.D., Georgi Benkovski Air Force Academy, Dolna Mitropoliya, Bulgaria, \\ zhpetrov@gmail.com
}

\begin{abstract}
The problems requiring managerial decisions are common for all countries in the Euro-Atlantic community regardless of the status of each individual country. Regardless the involved state is a member of the North Atlantic Treaty Organization (NATO) or its partner. Some of these problems have already existed for decades but have become particularly acute over the last twenty years. These problems include the reduction of troops and spending on post-Cold War peace dividends as well as the need of an increase in the number of mobile armed forces capable of operating far beyond the borders of their countries and whose actions have to be supported for a very long periods of time.
\end{abstract}

Keywords: management, defense planning, armed forces, strategic goals.

\section{INTRODUCTION}

From a historical standpoint the defense management has emerged as a topic of interest to the defense sector fairly recently. Western countries introduce a defense management concept in the process of solving problems like allocating financial or human resources, solving strategic and operational tasks as part of an integrated approach or using business-specific defense management tools. Such an approach requires highly professional and dedicated efforts at all levels and in all divisions of the state military organization. One of the proven ways of achieving this goal is the use of planning management functions, organization, leadership and control in all areas of the defense organization, which can contribute to maximizing the effectiveness of the armed forces' operational activities. The problems requiring managerial decisions are the same for all countries in the Euro-Atlantic community, regardless of the status of each country, whether it is a member of the North Atlantic Treaty Organization (NATO) or its partner. Some of these problems have existed for decades, but have become increasingly acute over the last twenty years. These problems include the reduction of troops and spending on post-Cold War peace dividends as well as the need of an increase in the number of mobile armed forces capable of operating far beyond the borders of their countries and whose actions have to be supported for a very long periods of time. In order for the implementation of managerial approaches to be considered they must address these and other similar problems while also be placed in the general context of the public interest according to the state of defense. Furthermore, in requests related to the actions and the results from these actions of the defense sector as a whole in particular the defense forces and resources. The fulfillment of this condition is of particular importance given the fact that in the absence of incentives or pressure from above any publicly funded organization, including the defense organization, is unlikely to undertake its own initiatives for the increase of the effectiveness of its activities. Thus every theoretical approach towards defense management must be closely linked to the sphere of democratic control over the defense sector and the armed forces (Antonov, Tsonev, 2016; Stoev, Zaharieva, Mutkov, 2019). There is no single commonly accepted definition of the term "defense 
management". The term simply covers the idea that defense organizations need to implement defense policies into practice and that they must create reliable and effective planning mechanisms, security systems and infrastructure. The modernization of the defense sector is a critical issue that has been addressed to the governments of the Euro-Atlantic community for at least the last fifteen years. Some states are focused on transforming their armed forces in order for them to better respond to 21 st century security threats. Other states undertake a more ambitious restructuring of the entire defense sphere in order to create new defense institutions. This process is especially true for post-communist states that are on the path of democratic transformation as well as for states that are currently in the last stage of these transformations.

All of these states expect strategic results from the reform of their defense and security sectors, correctly considering the success of these transformations as a factor contributing to their integration into the EuroAtlantic community as well as a factor in strengthening their own security and the prosperity of their people.Achieving these strategic goals requires a more rational allocation of scarce public resources, a more efficient use of such resources and a more visible and controlled outcome of government programs, including the defense oriented ones (Antonov, Hristozov, 2017; Terziev, Bankov, Georgiev, 2018). In many countries public administration is replacing its rather rigorous and rather bureaucratic form of activity on behalf of society with more flexible and distinct public sector governance with the number of these countries steadily increasing. But in this case a question arises: how can the government "build defense" more effectively? Part of this answer lies in the level of implementation of the optimal management practices in the defense sector that are accepted in the business sector, where the achievement of the intended results is of paramount importance for the survival of each organization in the competitive environment.

The cooperation initiative NATO/EAPC called "Partnership Action Plan on Defense Institution Building" (PAP-DIB) provides several examples of how domestic incentives to reform a country's defense sector through its more effective institutionalization are matched by international interest in supporting relevant programs. Part of this initiative is directly related to the concept of defense management.

Management planning is different from military operation planning, but it has a direct impact on the development of the armed forces structure or on the purchase of basic military equipment. What defense management can provide is to connect people in defense organizations who are prepared to accomplish their assigned tasks, with equipment and weaponry, and with comprehensive support to more effectively achieve their defense goals and objectives.

\section{DEFENSE PLANNING AND DEFENSE MANAGEMENT}

Parliaments and defense organizations of many partner countries as well as some of the new NATO members still face certain problems related to the concept of defense policy, the link between policy and planning, the concept of defense potential, the relationship between plans and budgets, the link between structural changes and technical modernization and other important and costly activities. This is not surprising given that unlike in NATO, the decision-making and planning processes in the former Warsaw Pact countries have been fully centralized. The countries of the former Warsaw Pact with the exception of Russia little to no knowledge and experience about defense policy and planning. Moreover, in the last decade of the 20th century the defense organizations of the former Warsaw Pact and post-Soviet republics constituted only a small fraction of immature and generally weak democratic institutions. As a result of this approach very few of its new members are able to make a significant contribution to the Alliance's potential during NATO accession.

This study examines the importance of the defense policy and the transparency of long-term and structural reform plans for democratic governance in the defense sector. It also discusses the characteristics of short, medium and long-term planning as well as the relationships between the respective processes, which indicate why defense planning is one of the key processes in defense management (Antonov, 2017a; Terziev, Petkova - Georgieva, 2019b).

A framework model for ensuring coherence between military policy objectives and structural change is presented and the importance and role of risk planning is explained. A brief description of the context of the defense planning process at a national level is presented and the importance of transparency of decisionmaking processes in terms of democratic accountability and the effectiveness of the actions of the defense department are highlighted.I will try to help the civilian and military experts of each country involved in the creation of democratic governance in the field of defense to better understand the link between security challenges and the political goals of defense planning and on the other hand the mechanisms for defense planning and resource management.

Regardless of how "perfect" the system implemented in the Ministry of Defense, accounting and how transparent financial procedures are they must ensure the development of an organizational structure 
appropriate to the situation, political goals and strategy of the country (Stoev, Zaharieva, Borodzhieva, 2019a; Terziev, Bankov, Georgiev, 2018a).

\section{ALTERNATIVE APPROACHES FOR LONG-TERM DEFENSE PLANNING}

The two most credible defense planning sources provide similar definitions about the defense planning approaches. In the 2004 edition, Bartlett, Holman and Soames offered nine options (Terziev, Petkova Georgieva, 2019c).

In a top-down approach interests, goals and strategies determine the decision directions according to the structure of the armed forces. In the bottom-up version the focus is based on enhancing existing defense capabilities and improving their respective weapon systems: first, the ability to meet the requirements for ongoing operations and operational plans is improved. In the case of scenario based approaches in which planners model several typical situations with each situation providing specific conditions for the use of the armed forces. These scenarios are then used to identify tasks that are aimed at achieving the goal and providing suitable opportunities.

In two closely related and complementary approaches respectively based on threat and vulnerability assessment, plan developers are looking for ways to address the problems associated with identified threats and the potential weaknesses of the potential adversary. Then the requirements for military capabilities are determined in comparison to the capabilities of the potential adversary (Terziev, Arabska, Dzhumalieva, 2016a; Terziev, Dzhumalieva, 2015; Nichev, 2009).

The approach - "key responsibilities and tasks" - is functional. In this approach the capability requirements for the Armed Forces and Allied Forces are determined independently of the scenarios, threats or identified weaknesses of the potential adversary. Instead they are defined as key responsibilities for example, to ensure air supremacy at all costs. Then depending on these key responsibilities, requirements are created to create the required set of capabilities as well as separate groups of requirements in the event of peace, crisis orconflict. The capability-based approach also provides for functional analysis. The functions and tasks that must be performed during the envisaged operations are transformed into requirements for capabilities. On this basis, planners develop force grouping options to provide these capabilities as efficiently and costeffectively as possible. By reinsurance, planners try to minimize the risks associated with the preparation of troops for every current objective as well as objectives that may occur after thirty or more years. At the same time, the requirements approved will be sufficient to provide the necessary balance and flexibility to deal with a variety of challenges and threats although the cost of these measures will be extremely high (Terziev, Dzhumalieva, 2016b-e).

Using the following approach planners are trying to achieve strategic and operational superiority based on technology. This approach is based on the belief that knowledge, creativity and innovation will provide the best systems and therefore a significant military advantage. Finally, in the fiscal approach to defense planning, decisions on the structure of the armed forces are determined by budget constraints.

Another authoritative source is the Handbook on Long Term Defence Planning issued by the NATO Research and Technology Organization. It offers a slightly different set of possible approaches to long-term planning. It is presented in the form of a three-component structure depending on the main purpose of the defense analysis. When the planning process is paramount, analysts distinguish top-down planning and limited resource planning (Stoykov, 2011-a; Stoykov, 2002; Stoykov, 2003; Stoykov, 2005).

In accordance on the level of optimism about the capabilities of new technologies or, on the other hand, the desire to adhere to historically proven facts, experienced designers apply four possible approaches:

- Technological optimism;

- Risk avoidance;

- Planning through gradual construction;

- Accounting for historical experience.

The last three approaches are based on proven concepts, the existing organizational structure, the capabilities of the Armed Forces and also adhere to the method of gradually improving efficiency and profitability. Under certain conditions they may be similar to the bottom-up variants described above. The following three approaches differ when the focus is on the features or specific scenarios that determine the level of effectiveness of the future structure of the armed forces. These approaches include capability-based planning, scenario-based planning and threat-based planning. Each of these approaches has its advantages and disadvantages which are rarely implemented in their 'pure' form. Virtually a defense planning approach 
may have the characteristics of two or more different possibilities. According to the Handbook, mature defense planning systems are today dominated by two approaches. This is resource-oriented planning (a softer form of resource-limited planning) and scenario-based. Since the publication of the Handbook in 2003 major defense planning efforts have been focused on enhancing the focus on capabilities and introducing the latest operational concepts. In particular an "impact-oriented" approach to operations. They goal to increase the flexibility of mechanisms for strategy development and planning and the response speed to changes in the security situation (Terziev, Bogdanova, Kanev, Georgiev, 2019b-d; Petrov, Georgiev, 2019e; Terziev, Georgiev, 2017b).

\section{CONCLUSION}

The conducted comparative analysis of the EU defense planning methodology compared to US and NATO defense planning shows that this methodology is largely similar. This applies in particular to the structure and logic of planning, its geographical coverage and the significant publicity component of public documents. Like the US and NATO the EU makes little use of strategic forecasting in its security and defense planning and places the principle of 'strategic uncertainty' at the forefront. Dynamic forecasting elements are widely used in EU planning especially in the short term. The EU has gone even further in this field applying a technique that can be arbitrarily called "dynamic planning". The EU methodology for planning in the field of defense has some major characteristics related to the fact that the EU is mainly a civic organization where military matters occupy only a small, albeit rather important place. Therefore, priority in planning is given to the support of civilian efforts to ensure security and last but not least the use of armed force. This predetermines the fact that the main focus of EU policy is on instruments such as crisis management, political stability, peacekeeping operations and the participation of other countries in various forms of partnership and cooperation (Terziev, Nichev, 2017c-i; Terziev, Nichev, Bogdanov, 2017j-k; Terziev, Madanski, Georgiev, 2017I-m).

\section{REFERENCE LIST}

Antonov, S., Hristozov, I. (2017). Otsenka na vazmozhnostite na polevite sistemi za komandvane i upravlenie za poddarzhane na eksploatatsiyata na vaorazhenieto i tehnikata, Sbornik dokladi ot godishnata nauchna konferentsiya na fakultet „Natsionalna sigurnost i otbrana" - "Savremenni predizvikatelstva pred sigurnostta i otbranata”, Parva chast, Sofiya, Voenna akademiya "Georgi Stoykov Rakovski“, 2017, str. 99-104, ISBN 978-954-9348-92-7 (Антонов С., Христозов И. Оценка на възможностите на полевите системи за командване и управление за поддържане на експлоатацията на въоръжението и техниката, Сборник доклади от годишната научна конфреренция на фракултет „Национална сигурност и отбрана“ - “Съвременни предизвикателства пред сигурността и отбраната”, Първа част, София, Военна академия „Георги Стойков Раковски“, 2017, стр. 99-104, ISBN 978-954-9348-92-7).

Antonov, S. I., Tsonev T. (2016). Possibilities for automation of designing elements of small arms using CAD/CAM/CAE systems”, Collection of papers: „Defense And Security, Mechanical Engineering And Military Technology, Communication And Computing Technologies, Social Science", Shumen, Bulgaria 2016, p.p.319-324, "Vasil Levski" National Military University - Artillery, Air Defense and CIS Faculty, Shumen, Bulgaria, ISSN 2367-7902.

Antonov, S. (2017a). Comparative analysis of the armament and equipment support modules in the field of command and control information systems of NATO armies, International Scientific Journal "SECURITY \& FUTURE", Year I, Issue 4, 2017, pp. 163-167, WEB ISSN 2535-082X; PRINT ISSN 2535-0668.

Stoev, I., Zaharieva, S., Mutkov, V. (2019). Evaluation of Gross Errors in Measured Temperature with an Electronic System for Management of Residential Energy Systems, International Scientific Conference 27th Telecommunications Forum, ISBN: 978-1-7281-4789-5, pp 454-457.

Stoev, I., Zaharieva, S., Borodzhieva, A. (2019a). An Approach for Assessment of the Synchronization Between Digital Temperature Sensors, International Scientific Conference 27th Telecommunications Forum, ISBN: 978-1-7281-4789-5, pp 458-461.

Terziev, V., Bankov, S., Georgiev, M. (2018). The Change in the approach of the court of justice of the European Union in the context of market freedoms and internal situations. // Journal of Innovations and Sustainability, Plovdiv, Bulgaria, 4, 2018, 3, pp. 85-112, ISSN 2367-8127 (CD-ROM), ISSN 2367- 
8151 (on-line).

Terziev, V., Bankov, S., Georgiev, M. (2018a). The Stability and growth pact: pursuing sound public finances and coordinating fiscal policies in the EU member states. // Journal of Innovations and Sustainability, Plovdiv, Bulgaria, 4, 2018, 3, pp. 53-68, ISSN 2367-8127 (CD-ROM), ISSN 2367-8151 (on-line).

Terziev, V., Petkova - Georgieva, S. (2019b). The performance measurment system key indicators and the determinants impact on the level of decentralization using as an example a subdivisional unit from the Bulgarian social health and care experience. // Proceedings of SOCIOINT 2019- 6th International Conference on Education, Social Sciences and Humanities 24-26 June 2019- Istanbul, Turkey, International Organization Center of Academic Research, Istanbul, Turkey, 2019, pp. 515-524, ISBN: 978-605-82433-6-1.

Terziev, V., Petkova - Georgieva, S. (2019c). A research study of nonlinearity experiencing in the rate of current account deficit to the Bulgarian health and care national product. // Proceedings of SOCIOINT 2019- 6th International Conference on Education, Social Sciences and Humanities 24-26 June 2019Istanbul, Turkey, International Organization Center of Academic Research, Istanbul, Turkey, 2019, pp. 525-533, ISBN: 978-605-82433-6-1.

Terziev, V., Arabska, E., Dzhumalieva, A. (2016a). Dostapnost do pazara na truda i sotsialna adaptatsiya na osvobodenite ot balgarskata armiya voennosluzheshti i chlenovete na tehnite semeystva. // Nauchna konferentsiya na tema „Zashtita ot diskriminatsiya v Balgariya i Evropa“ po sluchay Denya na pravata na choveka, organizirana savmestno ot Akademiyata na MVR i Instituta za darzhavata i pravoto na BAN, Sbornik dokladi ot nauchna konferentsiya, AMVR, 10-11 dekemvri 2015 g., Sofiya, 2016 g., Reg. № URI 4581r - 2926/ 24.03.2016 g. na AMVR, str.16-33, ISBN 978-954-348-136-1 (Терзиев, В., Арабска, Е., Джумалиева, А. Достъпност до пазара на труда и социална адаптация на освободените от българската армия военнослужещи и членовете на техните семейства. // Научна конференция на тема „Защита от дискриминация в България и Европа“ по случай Деня на правата на човека, организирана съвместно от Академията на МВР и Института за държавата и правото на БАН, Сборник доклади от научна конференция, АМВР, 10-11 декември 2015 г., София, 2016 г., Рег. № УРИ 4581р - 2926/ 24.03.2016 г. на АМВР, стр.16-33, ISBN 978954-348-136-1).

Terziev, V., Dzhumalieva, A. (2015). Religiyata i vyarata v konteksta na vaprosa za zashtita ot diskriminatsiya. // Nauchna konferentsiya na tema „Zashtita ot diskriminatsiya v Balgariya i Evropa“ po sluchay Denya na pravata na choveka, organizirana savmestno ot Akademiyata na MVR i Instituta za darzhavata i pravoto na BAN, 10-11 dekemvri 2015 g., Sofiya, ISBN 978-954-348-136-1 (Терзиев, В., Джумалиева, А. Религията и вярата в контекста на въпроса за защита от дискриминация. // Научна конференция на тема „Защита от дискриминация в България и Европа“ по случай Деня на правата на човека, организирана съвместно от Академията на МВР и Института за държавата и правото на БАН, 10-11 декември 2015 г., София, ISBN 978-954-348-136-1).

Nichev, N. (2009). Historical analysis of the involvement of joint armed forces in humanitarian operations. 15th International Conference on Knowledge-Based Organization 26-28 Nov 2009: Military Sciences. Security and Defense, Conference Proceedings 1, Volume: 1, Pages: 104-108, Sibiu, Romania, 2009.

Terziev, V., Dzhumalieva, A. (2016b). Po nyakoi vaprosi otnosno diskriminatsiyata po priznak „pol” vav vrazka s gavkavite formi na zaetost. // Nauchna konferentsiya na tema „Zashtita ot diskriminatsiya v Balgariya i Evropa“ po sluchay Denya na pravata na choveka, organizirana savmestno ot Akademiyata na MVR i Instituta za darzhavata i pravoto na BAN, Sbornik dokladi ot nauchna konferentsiya, AMVR, 10-11 dekemvri 2015 g., Sofiya, 2016 g., Reg. № URI 4581r - 2926/ 24.03.2016 g. na AMVR, str.2-15, ISBN 978-954-348-136-1 (Терзиев, В., Джумалиева, А. По някои въпроси относно дискриминацията по признак „пол” във връзка с гъвкавите фрорми на заетост. // Научна конференция на тема „Защита от дискриминация в България и Европа“ по случай Деня на правата на човека, организирана съвместно от Академията на МВР и Института за държавата и правото на БАН, Сборник доклади от научна конференция, АMBP, 10-11 декември 2015 г., София, 2016 г., Рег. № УРИ 4581р - 2926/ 24.03.2016 г. на AMBР, стр.2-15, ISBN 978954-348-136-1).

Terziev, V., Dzhumalieva, A. (2016c). Diskriminatsiyata po priznak: pol vav vrazka s prilaganeto na gavkavite formi na zaetost na natsionalniya pazar na truda. // XI Mezhdunarodnoy nauchnoy konferentsii „Innovatsii v tehnologiyah i obrazovanii", 18-19 Marta 2016 g., Kuzbasskiy gosudarstvennayy tehnicheskiy universitet im. T.F. Gorbacheva, Belovo, 4, 2016, ISBN 978-5-906888-04-4, s.219-233 
(Терзиев, В., Джумалиева, А. Дискриминацията по признак: пол във връзка с прилагането на гъвавите форми на заетост на националния пазар на труда. // XI Международной научной конференции „Инновации в технологиях и образовании", 18-19 Марта 2016 г., Кузбасский государственный технический университет им. Т.Ф. Горбачева, Белово, 4, 2016, ISBN 978-5906888-04-4, c.219-233).

Terziev, V., Dzhumalieva, A. (2016d). Dostapnost do pazara na truda i sotsialna adaptatsiya na osvobodenite ot balgarskata armiya voennosluzheshti i chlenovete na tehnite semeystva. // XI Mezhdunarodnoy nauchnoy konferentsii „Innovatsii v tehnologiyah i obrazovanii", 18-19 Marta 2016 g., Kuzbasskiy gosudarstvennayy tehnicheskiy universitet im. T.F. Gorbacheva, Belovo, 4, 2016, ISBN 978-5-906888-04-4, s.233-253 (Терзиев, В., Джумалиева, А. Достъпност до пазара на труда и социална адаптация на освободените от българската армия военнослужещи и членовете на техните семейства. // XI Международной научной конференции „Инновации в технологиях и образовании", 18-19 Марта 2016 г., Кузбасский государственный технический университет им. Т.Ф. Горбачева, Белово, 4, 2016, ISBN 978-5-906888-04-4, с.233-253).

Terziev, V., Dzhumalieva, A. (2016e). Po nyakoi vaprosi na religiyata i vyarata v konteksta na vaprosa za zashtita ot diskriminatsiya. // XI Mezhdunarodnoy nauchnoy konferentsii „Innovatsii v tehnologiyah i obrazovanii", 18-19 Marta 2016 g., Kuzbasskiy gosudarstvennayy tehnicheskiy universitet im. T.F. Gorbacheva, Belovo, 4, 2016, ISBN 978-5-906888-04-4, s.253-261 (Терзиев, В., Джумалиева, А. По някои въпроси на религията и вярата в контекста на въпроса за защита от дискриминация. // XI Международной научной конференции „Инновации в технологиях и образовании", 18-19 Марта 2016 г., Кузбасский государственный технический университет им. Т.Ф. Горбачева, Белово, 4, 2016, ISBN 978-5-906888-04-4, c.253-261).

Stoykov, Mitko. (2011). Crisis and emergency response capabilities - Republic of Bulgaria, NATO Advanced Research Workshop on Sustained Emergency Relief - Regionally Developed Capacities, IOS Press, Nieuwe Hemweg 6B, 1013 BG Amsterdam, Netherlands, Web of Science, Proceedings Paper, ID: WOS:000351360000016, ISBN:978-1-61499-315-5; 978-1-61499-314-8, ISSN: 1879-8268, pp.: 5968 Security and Defence http://ebooks.iospress.nl/volumearticle/35344, 2011.

Stoykov, Mitko. (2011a). Development of Crisis Management and Disaster Response Centre of Excellence (CMDR COE) Bulgarian Contribution to NATO Smart Defence, NATO Advanced Research Workshop on Sustained Emergency Relief - Regionally Developed Capacities, IOS Press, Nieuwe Hemweg 6B, 1013 BG Amsterdam, Netherlands, Web Of Science, Proceedings Paper, ID:

WOS:000351360000016, ISBN:978-1-61499-315-5; 978-1-61499-314-8, ISSN: 1879-8268, pp.: 18 24 Security and Defence http://ebooks.iospress.nl/volumearticle/35335; 2011.

Stoykov, Mitko. (2002). Informatsionni resheniya za natsionalnata sigurnost - Mrezhovo-tsentrichnata voyna, Voenen zhurnal, br.6, 2002 g. str. 69-79, ISSN 0861-7392 (Стойков, Митко. Информационни решения за националната сигурност - Мрежово-центричната война, Военен журнал, бр.6, 2002 г. стр. 69-79, ISSN 0861-7392).

Stoykov, Mitko. (2003). Neobhodimost ot promeni v planiraneto na otbranata - paketirane na potentsialnite vazmozhnosti na misiite, Voenen zhurnal, br. 1, 2003 g. str 102-112, ISSN 0861-7392 (Стойков, Митко. Необходимост от промени в планирането на отбраната - пакетиране на потенциалните възможности на мисиите, Военен журнал, бр. 1, 2003 г. стр 102-112, ISSN 0861-7392).

Stoykov, Mitko. (2005). Transformirashto liderstvo na transformatsiyata na sistemata za sigurnost, Voenen zhurnal, br. 2, 2005 g. str. 16-35, ISSN 0861-739 (Стойков, Митко.Трансформиращо лидерство на трансформацията на системата за сигурност, Военен журнал, бр. 2, 2005 г. стр. 16-35, ISSN 0861-739).

Terziev, V., Bogdanova, M., Kanev, D., Georgiev, M. (2019b). The cadets and the reasons for their drop-out of the National Military University. // Proceedings of ADVED 2019 - 5th International Conference on Advances in Education and Social Sciences, 21-23 October 2019, International Organization Center of Academic Research, Istanbul, Turkey, 2019, pp. 398-406, ISBN: 978-605-82433-7-8.

Terziev, V., Bogdanova, M., Kanev, D., Georgiev, M. (2019c). The cadets from the military schools as subjects of educational activity. // Proceedings of ADVED 2019 - 5th International Conference on Advances in Education and Social Sciences, 21-23 October 2019, International Organization Center of Academic Research, Istanbul, Turkey, 2019, pp. 407-418, ISBN: 978-605-82433-7-8.

Terziev, V., Bogdanova, M., Kanev, D., Georgiev, M. (2019d). Uses of the strategic card in the republic of Bulgaria's land forces. // Proceedings of ADVED 2019 - 5th International Conference on Advances in 
Education and Social Sciences, 21-23 October 2019, International Organization Center of Academic Research, Istanbul, Turkey, 2019, pp. 519-525, ISBN: 978-605-82433-7-8.

Petrov, N., Georgiev, M. (2019e). Assessing of the military professional competencies. // Proceedings of SOCIOINT 2019- 6th International Conference on Education, Social Sciences and Humanities 24-26 June 2019- Istanbul, Turkey, International Organization Center of Academic Research, Istanbul, Turkey, 2019, pp. 462-472, ISBN: 978-605-82433-6-1.

Terziev, V., Georgiev, M. (2017b). Highlights of the evolution of the „balanced scorecard” idea as a model for managing strategy development and control. // Proceedings of SOCIOINT 2017- 4th International Conference on Education, Social Sciences and Humanities 10-12 July 2017- Dubai, UAE, 2017, ISBN: 978-605-82433-1-6, pp.607-610.

Terziev, V., Nichev, N. (2017c). Streamlining management solutions for economic, effective and efficient spending of resources for security and defense. // Proceedings of SOCIOINT 2017- 4th International Conference on Education, Social Sciences and Humanities 10-12 July 2017- Dubai, UAE, 2017, ISBN: 978-605-82433-1-6, pp.667-671.

Terziev, V., Nichev, N. (2017d). Some aspects on forming preparedness of logistics military officers for management activities. // Proceedings of SOCIOINT 2017- 4th International Conference on Education, Social Sciences and Humanities 10-12 July 2017- Dubai, UAE, 2017, ISBN: 978-605-82433-1-6, pp.631-635.

Terziev, V., Nichev, N. (2017e). Research, Identification and monitoring of the needs of occupational training of social activities experts. // Proceedings of SOCIOINT 2017- 4th International Conference on Education, Social Sciences and Humanities 10-12 July 2017- Dubai, UAE,2017, ISBN: 978-60582433-1-6, pp.556-574.

Terziev, V., Nichev, N. (2017f). Model of methodology for determining the needs of continuing vocational training of social work specialists providing social services. // Proceedings of SOCIOINT 2017- 4th International Conference on Education, Social Sciences and Humanities 10-12 July 2017- Dubai, UAE, 2017, ISBN: 978-605-82433-1-6, pp.541-555.

Terziev, V., Nichev, N. (2017g). Strategic framework for social entrepreneurship development in Bulgaria. // Proceedings of SOCIOINT 2017- 4th International Conference on Education, Social Sciences and Humanities 10-12 July 2017- Dubai, UAE, 2017, ISBN: 978-605-82433-1-6, pp.531-540.

Terziev, V., Nichev, N. (2017h). Main features of the offsets in defense trade. Proceedings of SOCIOINT 2017- 4th International Conference on Education, Social Sciences and Humanities 10-12 July 2017Dubai, UAE, 2017, ISBN: 978-605-82433-1-6, pp.661-666.

Terziev, V., Nichev, N. (2017i). Analysis of the environment for military educational system functioning and its impact on the preparation of cadets for military professional activities in the republic of Bulgaria. // Proceedings of SOCIOINT 2017- 4th International Conference on Education, Social Sciences and Humanities 10-12 July 2017- Dubai, UAE, 2017, ISBN: 978-605-82433-1-6, pp.627-630.

Terziev, V., Nichev. N., Bogdanov, P. (2017j). Comparative analysis of the formation of military professional skills in the cadets to be trained in logistics specializations. // Proceedings of ADVED 2017-3rd International Conference on Advances in Education and Social Sciences 9-11 October 2017- Istanbul, Turkey, 2017, ISBN: 978-605-82433-0-9, pp.671-677.

Terziev, V., Nichev, N., Bogdanov, P. (2017k). Prospects for development of higher education in Bulgaria. // Proceedings of ADVED 2017- 3rd International Conference on Advances in Education and Social Sciences 9-11 October 2017- Istanbul, Turkey, 2017, ISBN: 978-605-82433-0-9, pp.678-689.

Terziev, V., Madanski, V., Georgiev, M. (2017I). Offset implementation impact on technology transfer in Bulgaria. // Proceedings of ADVED 2017- 3rd International Conference on Advances in Education and Social Sciences 9-11 October 2017- Istanbul, Turkey, 2017, ISBN: 978-605-82433-0-9, pp.743-747.

Terziev, V., Madanski, V., Georgiev, M. (2017m). Offset as an economic operation and a trade practice. // Proceedings of ADVED 2017- 3rd International Conference on Advances in Education and Social Sciences 9-11 October 2017- Istanbul, Turkey, 2017, ISBN: 978-605-82433-0-9, pp.748-753. 